\title{
DEVELOPING AN ATTITUDINAL SCALE TO MEASURE THE ATTITUDES OF THE FARMERS TOWARDS COMMERCIALIZATION OF AGRICULTURAL EXTENSION
}

\author{
R P Mahaliyanaarachchi ${ }^{1}$, A W Wijeratne ${ }^{2}$ and R M A S Bandara ${ }^{2}$
}

\begin{abstract}
Agricultural Extension is one of the major sub sectors of the agricultural sector which has been given major concern by governments, international funding agencies such as FAO, IFAD, ADB and World Bank and other donor agencies mainly due to high cost incurred in agricultural extension programs. In the mean time most of the governments both in the developing and developed world has been pruning funds for the extension services since 1990s. The situation of the public extension service has been deteriorating due to this reason. Therefore the structural and financial adjustments in the extension system have been demanded. In this climate the experts in the extension field have identified privatisation and commercialisation of agricultural extension as an important alternative.
\end{abstract}

Before implementing commercialisation approach, it is necessary to know the attitudes of the farmers who are the major participants in agricultural production and development towards commercialisation of agricultural extension. Measuring attitudes as a psychological natural tendency provides a basis for planning and also affects desirable changes in the existing system. The prime objective of this study was to develop a scale to measure the attitudes of the farmers towards commercialisation of agricultural extension. Attitude towards commercialisation of agricultural extension service (CAES) refers to the "individual's degree of willingness or unwillingness towards commercialisation of agricultural extension service."

Initially 41 statements were developed and out of these only 30 statements were identified as reliable statements. Out of 30 statements remained after validity test, 19 are identified as positive statements and 11 are as negative.

Key words: Agricultural Extension, Commercialization Approach, Attitudes, Attitudinal scale

\section{INTRODUCTION}

Agriculture still contributes significantly and substantially to the Gross Domestic Production (GDP) of many developing countries. It was 22 percent in Sri Lanka and 25 percent in India in 1998. At present agriculture is considered not only as a sector of the rural economy but also as a modern industry, which can bring millions of dollars into the country. The governments of these countries often perceive agricultural sector as a strategic one resulting self-sufficiency in staples to the possible extent and exports as well. Therefore it is obvious that more emphasize should be given to agricultural sector in these developing countries. It visualizes in the policies driven by international donor agencies such as FAO, World Bank, IFAD, etc. These organizations still provide big grants to development of agricultural sector. Agricultural Extension is one of the major sub sectors of the agricultural sector which

${ }^{1}$ Professor in Agribusiness Management, Faculty of Agricultural Sciences, Sabaragamuwa University of Sri 26

${ }^{2}$ Lecturer, Faculty of Agricultural Sciences, Sabaragamuwa University of Sri Lanka, Belihuloya, Sri Lanka. 
has been given main concern by these donors.

In the mean time most of the governments both in the developing and developed world has been pruning funds for the development of agricultural sector including extension services since 1990s. The situation of the public extension service has been deteriorating due to this reason. In this situation government extension service is criticized for wasting public funds \& resources and lack of efficiency. Therefore the structural and financial adjustments in the extension system have been demanded. In this climate the experts in the extension field have identified privatisation and commercialisation of agricultural extension as an important alternative.

Today, most of the developing countries are moving away from welfare approaches. Under this concept it has been started to consider agricultural extension as a 'private good' as other agricultural inputs such as fertilizer, seeds, agro chemicals, machinery, etc.

Before the implementation of commercialisation approach, it is necessary to know the attitudes of the different key participants in agricultural production and development such as agricultural scientists, extension personnel and farmers towards commercialisation of agricultural extension. Measuring attitudes as a psychological natural tendency provides a basis for planning which in turn affects on desirable changes in the existing system. It was identified that there is a necessity to have a scientifically accepted attitudinal scale to measure attitudes of the farmers towards commercialisation of agricultural extension service.
The prime objective of this study is to propose an attitudinal scale to measure attitudes of the farmers towards commercialisation of agricultural extension service.

\section{Definition of Attitudes towards CAES}

Attitude towards commercialisation of agricultural extension service (CAES) refers to the "individual's degree of willingness or unwillingness towards commercialisation of agricultural extension service."

\section{Why Commercialisation, not Privatisation?}

Privatisation is mainly changing the ownership of the extension service to private sector from public sector. The extension services are mainly funded and delivered by government agencies free of charge for decades. People in most of the developing countries including Sri Lanka have unpleasant experiences of privatisation. This has made the concept of commercialisation came into practice.

\section{RESEARCH METHOD}

\section{Selection of Farmers for the Study}

The research was conducted in the Belihuloya region of the Ratnapura district in Sri Lanka where nearly 80 percent of the population is farmers. This area was selected due to three reasons.

- Majority of the farmers involve in both paddy and vegetable cultivation.

- They have experienced well organized government sector extension service once (before 1989) and today they are experiencing both government and various private sector extension services. 
- Close proximity to the researchers. This was enabling to test reliability with higher accuracy while it could be dealt with same group of farmers.

The list of farmers (sampling frame) was obtained from the agrarian services centre of the area and 40 framers were selected for the study. To obtain unbiased and true ideas of the farmers on CAES, experienced farmers both with government extension service and various private sector extension services were used. This was determined at the pre-testing stage. The majority of selected farmers were satisfactorily educated farmers and their demographic characteristics were almost homogenous. This was practiced in order to obtain unbiased ideas on CAES.

\section{Preparation of questionnaires}

First, a questionnaire was prepared by the senior researcher by using own experiences in the agricultural extension field including 28 positive and 23 negative statements on CAES. Then the questionnaire was pre-tested with 5 colleagues. According to their opinions wordings and organization of the statements were adjusted. Then the revised questionnaire was sent to 26 selected experts to test the validity. Considering the experts comments on the validity of the statements, the questionnaire was revised and presented to the selected group of farmers to test reliability.

\section{Organization of the research}

Eight enumerators were used to collect data. Each enumerator was asked to interview five farmers. They were asked to complete interview process within three days at the first stage. They were instructed to record the details of the farmers enabling them to interview the same farmers after one month period. The same group of farmers was interviewed by the same enumerators after one month (30 days) period to test the reliability of the statements.

\section{Test of Validity}

To test the validity of initially selected 51 statements, a seven point rating scale was used. Statements were sent to 26 scientists and academics those who are in the agricultural sector. They were asked to give a rating scale for each statement regarding the validity of using such statements to disclose attitude of farmers on CAES. The seven point rating scale ranged from Excellent $=6$, Very good $=5$, Good $=$ 4 , Fair $=3$, Poor $=2$, Very poor $=1$ to Not valid $=0$. A logical function in Excel was run to filter the valid statements, if average score is grater than or equal to 4 and more than $75 \%$ of scientists have given rating score more than or equal to 4 .

\section{Test of Reliability}

It is required to keep statements for the attitudinal scale, which are reliable. After validity test, 41 statements were kept for the validity test. In order to know farmers' attitudes towards CAES, the agreement of farmers on each statement was obtained through a five point rating scale i.e. Strongly agree $=1$, Agree $=2$, Moderately agree $=3$, Not agree $=4$, and Strongly not agree $=5$. An interview schedule containing 41 statements was administered among a sample of 40 farmers in Belihuloya area. Farmers were asked to mark their agreement against each statement according to the rating scale. The same process was repeated one month after initial data collection for the same sample 
assuming that farmers have forgotten the rating score given for each statement at initial collection of data. Sum of the scores of each statement was ranked form 1 to 40 and analysis of Spearman's coefficient of rank correlation (r) was performed between initial rank and final rank of each statement.

$$
\frac{\mathrm{r}=1-6 \sum_{i=1}^{n} d_{i}^{2}}{\mathrm{n}\left(\mathrm{n}^{2}-1\right)}
$$

Where, $\mathrm{n}=$ number of observations, $\operatorname{di} 2=\mathrm{R}\left(\mathrm{X}_{\mathrm{i}}\right)-\mathrm{R}\left(\mathrm{Y}_{\mathrm{i}}\right), \mathrm{R}\left(\mathrm{X}_{\mathrm{i}}\right)=$ rank of initial score,

$\mathrm{R}\left(\mathrm{Y}_{\mathrm{i}}\right)=$ rank of final score. Statements that produced higher positive $r(r>0.6)$ at 0.05 level of significant were kept for the attitudinal score. Out of 41 statements, only 30 statements were identified as reliable statements.

\section{Statement-wise Analysis}

Out of 30 statements remained after validity test, 19 are identified as positive statements while the rest is negative. Mean and median score of each statement represents the general attitude of farmers on CAES. Percentage of farmers who responded to 1 - 5 rating scale was obtained. Overall attitude of farmers on CAES based on positive and negative statements were taken as least favorable, favorable and most favorable based on average value of sum of statements and confidence interval. For positive statements the sum of score is ranged from 19 to 95 , while the central score to be 57 , which represents more or less neutral attitude (agreement/ disagreement) towards CAES. Any score below the centre (which should be significantly different from mean/median at a given level of probability) provides most favorable attitude towards CAES, while any score grater than centre measurement which should be also significantly different from centre provides least favorable attitude towards CAES based on positive statements.

The sum of score of negative statements is ranged from 11 to 55, while the centre measurement to be 33 . Any score below the centre, which is significantly different from it produces agreement with negative statements, which shows least favorable attitude towards CAES and vise-versa shows most favorable attitude towards CAES.

$\mathrm{CI}=\mu \pm \mathrm{t}_{(\alpha, \mathrm{df})} . \mathrm{Se}$

For positive statements,

Score of least favorable category $>\mu+$ $t_{(\alpha, d f)}$ Se

Score of most favorable category $<\mu$ $\mathrm{t}_{(\alpha, \mathrm{df})} . \mathrm{Se}$

\section{For negative statements,}

Score of least favorable category $<\mu$ $t_{(\alpha, d f)}$. Se

Score of most favorable category $>\mu+$ $\mathrm{t}_{(\alpha, \mathrm{df})}$. Se

Where, $\mu=$ grand mean of sum of scores of statements, $\mathrm{t}_{(\alpha, \mathrm{df})}=$ critical $\mathrm{t}$ value at $\alpha=0.05$, and $\mathrm{df}=$ degrees of freedom and $\mathrm{Se}=$ standard error of mean. Score of favorable category is the middle range or confidence interval (CI).

\section{RESULTS AND DISCUSSION}

\section{Probability Distribution Curves}

The figures 01 and 02 show the probability distribution curves and descriptive statistics of sum of scores of positive and negative statements 
respectively. Horizontal axis presents sum of scores while vertical axis presents frequency. As two distributions are approximately normally distributed, there is no harm in using $95 \%$ confidence interval of mean in order to determine the levels for least favorable, favorable and most favorable scores. Besides the $95 \%$ confidence interval for median is also very closer to the same of mean which should be used when distributions are not normal.

\section{Statement-wise Analysis}

Table 01 presents the detailed analysis of positive statements (Spearman's coefficient of rank correlation, prob $>|\mathrm{R}|$, mean and median score, rating scale and percentage of farmers in each rating score). According to statement 1 , about $95 \%$ of farmers have the agreement to consider extension as an input. Mean (1.875) and median (2) score of the statement also represent their agreement to consider extension as an input. In general, statements $6,7,12,14,16$ and 19 revealed the agreement of farmers to go for commercialized agricultural extension service while the statements $3,8,9,10,11,13,15,17$ and 18 disclosed the moderate agreement and rest of the statements (2, 4 and 5) disclosed the disagreement about the issue.

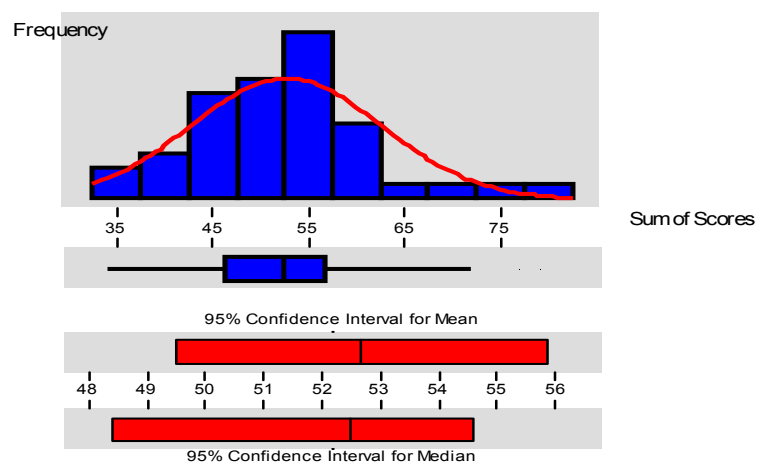

Figure 01: Distribution of Sum of Scores of Positive Statements

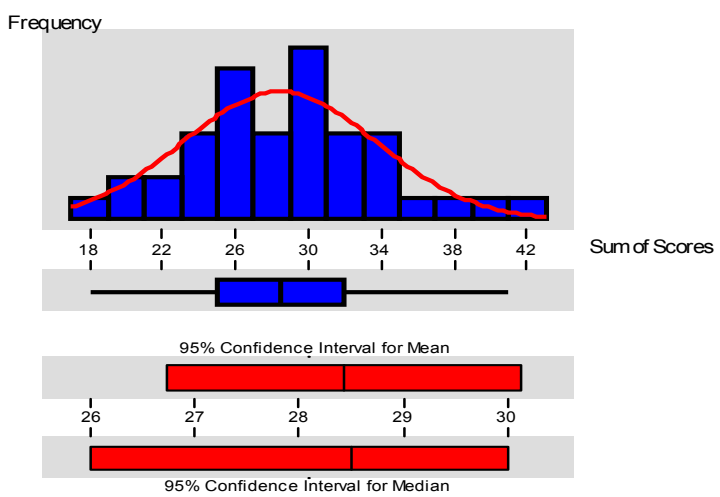

Figure 02: Distribution of Sum of Scores of Negative Statements 
Table 01: Positive Statements

\begin{tabular}{|c|c|c|c|c|}
\hline Statement & $\begin{array}{l}\text { r, } \\
\text { Prob }>|R|\end{array}$ & $\begin{array}{l}\text { Mean } \\
\text { (Median) }\end{array}$ & $\begin{array}{l}\text { Rating } \\
\text { Scale }\end{array}$ & Percentage \\
\hline $\begin{array}{l}\text { 1. Do you consider Extension as an } \\
\text { input? }\end{array}$ & $0.64(0.0001)$ & (2) & $\begin{array}{l}1 \\
2 \\
3 \\
4\end{array}$ & $\begin{array}{c}41.5 \\
34.1 \\
19.5 \\
4.9\end{array}$ \\
\hline $\begin{array}{l}\text { 2. Do you like to pay for } \\
\text { commercialized extension service? }\end{array}$ & $0.85(0.0001)$ & $\begin{array}{l}3.775 \\
\text { (4) }\end{array}$ & $\begin{array}{l}1 \\
2 \\
3 \\
4 \\
5\end{array}$ & $\begin{array}{c}4.9 \\
19.5 \\
12.2 \\
19.5 \\
43.9\end{array}$ \\
\hline $\begin{array}{l}\text { 3. Do you think that you can get } \\
\text { better service by paying which } \\
\text { increase the profitability }\end{array}$ & $\begin{array}{l}0.86 \\
(0.0001)\end{array}$ & $\begin{array}{l}2.975 \\
\text { (3) }\end{array}$ & $\begin{array}{l}1 \\
2 \\
3 \\
4 \\
5\end{array}$ & $\begin{array}{l}17.1 \\
24.4 \\
17.1 \\
26.8 \\
14.6\end{array}$ \\
\hline $\begin{array}{l}\text { 4. Do you think it is unfair to use } \\
\text { public funds for extension service? }\end{array}$ & $\begin{array}{l}0.69 \\
(0.0001)\end{array}$ & $\begin{array}{l}3.5 \\
(4)\end{array}$ & $\begin{array}{l}1 \\
2 \\
3 \\
4 \\
5\end{array}$ & $\begin{array}{l}7.3 \\
19.5 \\
12.2 \\
36.6 \\
24.4\end{array}$ \\
\hline $\begin{array}{l}\text { 5. Do you think that } \\
\text { commercialization leads to provide } \\
\text { basket of inputs such as planting } \\
\text { materials, fertilizer, technical advice } \\
\text { and marketing information? }\end{array}$ & $\begin{array}{l}0.61 \\
(0.0001)\end{array}$ & $\begin{array}{l}3.70 \\
(4)\end{array}$ & $\begin{array}{l}1 \\
2 \\
3 \\
4 \\
5\end{array}$ & $\begin{array}{c}2.4 \\
4.9 \\
31.7 \\
41.5 \\
19.5\end{array}$ \\
\hline $\begin{array}{l}\text { 6. Commercialization increases } \\
\text { overall efficiency of agric extension } \\
\text { service? }\end{array}$ & $\begin{array}{l}0.61 \\
(0.0001)\end{array}$ & $\begin{array}{l}2.625 \\
(2)\end{array}$ & $\begin{array}{l}1 \\
2 \\
3 \\
4 \\
5\end{array}$ & $\begin{array}{c}14.6 \\
41.5 \\
19.5 \\
14.6 \\
9.8\end{array}$ \\
\hline $\begin{array}{l}\text { 7. Commercialization increases } \\
\text { overall effectiveness of agric } \\
\text { extension service? }\end{array}$ & $\begin{array}{l}0.76 \\
(0.0001)\end{array}$ & $\begin{array}{l}2.35 \\
(2)\end{array}$ & $\begin{array}{l}1 \\
2 \\
3 \\
4 \\
5\end{array}$ & $\begin{array}{c}22 \\
48.8 \\
4.9 \\
22 \\
2.4\end{array}$ \\
\hline $\begin{array}{l}\text { 8. Relationship between the CAES } \\
\text { and private sector agencies will be a } \\
\text { positive one. }\end{array}$ & $\begin{array}{l}0.64 \\
(0.0001)\end{array}$ & $\begin{array}{l}2.55 \\
(3)\end{array}$ & $\begin{array}{l}1 \\
2 \\
3 \\
4 \\
5\end{array}$ & $\begin{array}{c}7.3 \\
51.2 \\
22 \\
17.1 \\
2.4\end{array}$ \\
\hline $\begin{array}{l}\text { 9. Commercialization increases both } \\
\text { technical and marketing information } \\
\text { availability to the farmers. }\end{array}$ & $\begin{array}{l}0.73 \\
(0.0001)\end{array}$ & $\begin{array}{l}2.75 \\
(3)\end{array}$ & $\begin{array}{l}1 \\
2 \\
3 \\
4 \\
5\end{array}$ & $\begin{array}{l}12.2 \\
34.1 \\
31.7 \\
14.6 \\
7.3\end{array}$ \\
\hline $\begin{array}{l}\text { 10. Competition between the service } \\
\text { providers will increase the quality of } \\
\text { the service }\end{array}$ & $\begin{array}{l}0.75 \\
(0.0001)\end{array}$ & $\begin{array}{l}2.45 \\
(3)\end{array}$ & $\begin{array}{l}1 \\
2 \\
3 \\
4\end{array}$ & $\begin{array}{l}24.4 \\
24.4 \\
36.6 \\
14.6\end{array}$ \\
\hline $\begin{array}{l}\text { 11. Farmer will accept and follow the } \\
\text { advices given by CAES, because } \\
\text { they pay for the required service. }\end{array}$ & $\begin{array}{l}0.71 \\
(0.0001)\end{array}$ & $\begin{array}{l}2.775 \\
(3)\end{array}$ & $\begin{array}{l}1 \\
2 \\
3 \\
4 \\
5\end{array}$ & $\begin{array}{c}17.1 \\
26.8 \\
26.8 \\
19.5 \\
9.8\end{array}$ \\
\hline
\end{tabular}




\begin{tabular}{|c|c|c|c|c|}
\hline \multirow{5}{*}{$\begin{array}{l}\text { 12. Extension workers in CAES can } \\
\text { maintain good rapport with the } \\
\text { research personnel }\end{array}$} & \multirow{5}{*}{$\begin{array}{l}0.65 \\
(0.0001)\end{array}$} & \multirow{5}{*}{$\begin{array}{l}2.725 \\
(2)\end{array}$} & 1 & 14.6 \\
\hline & & & 2 & 39.0 \\
\hline & & & 3 & 17.1 \\
\hline & & & 4 & 17.1 \\
\hline & & & 5 & 12.2 \\
\hline \multirow{5}{*}{$\begin{array}{l}\text { 13. The recognition of extension } \\
\text { workers of CAES is greater among } \\
\text { the farming community. }\end{array}$} & \multirow{5}{*}{$\begin{array}{l}0.77 \\
(0.0001)\end{array}$} & \multirow[t]{2}{*}{2.975} & 1 & 9.8 \\
\hline & & & 2 & 31.7 \\
\hline & & \multirow[t]{3}{*}{ (3) } & 3 & 22 \\
\hline & & & 4 & 24.4 \\
\hline & & & 5 & 12.2 \\
\hline \multirow{4}{*}{$\begin{array}{l}\text { 14. Extension worker in CAES can } \\
\text { devote more time for the extension } \\
\text { work due to lack of irrelevant duties } \\
\text { such as attending to government } \\
\text { meetings, political works etc. }\end{array}$} & \multirow{4}{*}{$\begin{array}{l}0.73 \\
(0.0001)\end{array}$} & \multirow[t]{2}{*}{2.25} & 1 & 24.4 \\
\hline & & & 2 & 46.3 \\
\hline & & \multirow[t]{2}{*}{ (2) } & 3 & 9.8 \\
\hline & & & 4 & 19.5 \\
\hline 15. Farmers have higher & 0.70 & \multirow[t]{2}{*}{3.00} & 1 & 17.1 \\
\hline \multirow{4}{*}{$\begin{array}{l}\text { trustworthiness of the information } \\
\text { disseminated by the CAES }\end{array}$} & \multirow{4}{*}{$(0.0001)$} & & 2 & 17.1 \\
\hline & & \multirow[t]{3}{*}{ (3) } & 3 & 29.3 \\
\hline & & & 4 & 22.0 \\
\hline & & & 5 & 14.6 \\
\hline \multirow{4}{*}{$\begin{array}{l}\text { 16. Farmers believe that government } \\
\text { extension service is not doing } \\
\text { enough service (inefficient). }\end{array}$} & \multirow{4}{*}{$\begin{array}{l}0.60 \\
(0.0001)\end{array}$} & \multirow[t]{2}{*}{2.075} & 1 & 31.7 \\
\hline & & & 2 & 41.5 \\
\hline & & \multirow[t]{2}{*}{ (2) } & 3 & 14.6 \\
\hline & & & 4 & 12.2 \\
\hline \multirow{5}{*}{$\begin{array}{l}\text { 17. Farmers believe that Government } \\
\text { Extension Workers are politicized }\end{array}$} & \multirow{5}{*}{$\begin{array}{l}0.72 \\
(0.0001)\end{array}$} & \multirow[t]{2}{*}{3.025} & 1 & 14.6 \\
\hline & & & 2 & 22.0 \\
\hline & & \multirow[t]{3}{*}{ (3) } & 3 & 22.0 \\
\hline & & & 4 & 29.3 \\
\hline & & & 5 & 12.2 \\
\hline 18. Extension Workers of the & 0.85 & \multirow[t]{2}{*}{2.9} & 1 & 9.8 \\
\hline Commercialized Extension Service & $(0.0001)$ & & 2 & 34.1 \\
\hline are highly qualified compared to & & \multirow[t]{3}{*}{ (3) } & 3 & 24.4 \\
\hline \multirow[t]{2}{*}{ Government Extension Workers. } & & & 4 & 19.5 \\
\hline & & & 5 & 12.2 \\
\hline 19. Extension Workers of the & \multirow{5}{*}{$\begin{array}{l}0.82 \\
(0.0001)\end{array}$} & \multirow[t]{3}{*}{2.45} & 1 & 19.9 \\
\hline Commercialized Extension Service & & & 2 & 41.5 \\
\hline have good relationship with other & & & 3 & 19.5 \\
\hline support services such as input & & (2) & 4 & 14.6 \\
\hline supplies market, etc. & & & 5 & 4.8 \\
\hline
\end{tabular}

Table 02: Attitudinal Score for Positive Statements

\begin{tabular}{llcc}
\hline $\begin{array}{l}\text { Category for } \\
\text { Positive Statement }\end{array}$ & Attitudinal Score & Frequency & Percentage \\
\hline Least Favorable & $>55.8653$ & & \\
Favorable & $49.4847-55.8653$ & 12 & 30.00 \\
Most Favorable & $<49.4847$ & 16 & 30.00 \\
Total & & 40 & 40.00 \\
\hline
\end{tabular}


Table 02 details the attitudinal score for least favorable, favorable and most favorable categories, frequencies and percentages of respondents of positive statements. The $95 \%$ confidence interval for grand mean of sum of scores (52.675) is ranged from 49.4847 to 55.8653 , which is the sum of scores of attitudinal score of favorable category of positive statements. Percentage of farmers in favorable category is $30 \%$ while it is $40 \%$ in most favorable category and $30 \%$ in least favorable category. Therefore in general, farmers have favorable attitudes towards CAES based on positive statements.
Table 03 details the results of statement-wise analysis of negative statements. About $15 \%$ of farmers were highly agreed with the statement that extension is an essential service, which should be provided by the government. According to central measurement $($ mean $=2.9$, median $=3)$ of the statement, farmers have a neutral agreement about the issue. The other negative statements that resulted neutral agreement are 5 and 6 . The statements which have been not agreed (positive attitude for negative statement; or double negative law) by farmers are 9 and 11. The agreement for rest of the negative statements $(2$, $3,4,8$ and 10) revealed the negative attitude for commercialization.

Table 03: Negative Statements

\begin{tabular}{|c|c|c|c|c|}
\hline Statement & $\begin{array}{l}\text { r, } \\
\text { Prob }>|R|\end{array}$ & $\begin{array}{l}\text { Mean } \\
\text { (Median) }\end{array}$ & $\begin{array}{l}\text { Rating } \\
\text { Scale }\end{array}$ & Percentage \\
\hline $\begin{array}{l}\text { 1. Do you consider Extension as } \\
\text { an essential service, which should } \\
\text { be provided by the government? }\end{array}$ & $\begin{array}{l}0.76 \\
(0.0001)\end{array}$ & $\begin{array}{l}2.9 \\
(3)\end{array}$ & $\begin{array}{l}1 \\
2 \\
3 \\
4 \\
5\end{array}$ & $\begin{array}{l}14.6 \\
26.8 \\
24.4 \\
22.0 \\
12.2\end{array}$ \\
\hline $\begin{array}{l}\text { 2. Commercialization neglects the } \\
\text { sustainability of farming systems }\end{array}$ & $\begin{array}{l}0.67 \\
(0.0001)\end{array}$ & $\begin{array}{l}2.4 \\
(2)\end{array}$ & $\begin{array}{l}1 \\
2 \\
3 \\
4 \\
5\end{array}$ & $\begin{array}{c}26.8 \\
31.7 \\
24.4 \\
9.8 \\
7.3\end{array}$ \\
\hline $\begin{array}{l}\text { 3. Commercialization of agric. } \\
\text { extension cannot be justified } \\
\text { because of bad experience of } \\
\text { commercialization in other } \\
\text { sectors. }\end{array}$ & $\begin{array}{l}0.69 \\
(0.0001)\end{array}$ & $\begin{array}{l}2.575 \\
(2.5)\end{array}$ & $\begin{array}{l}1 \\
2 \\
3 \\
4 \\
5\end{array}$ & $\begin{array}{l}14.6 \\
34.1 \\
31.7 \\
17.1 \\
2.4\end{array}$ \\
\hline $\begin{array}{l}\text { 4. Commercialization considers } \\
\text { only commercial aspects but not } \\
\text { social aspects. }\end{array}$ & $\begin{array}{l}0.65 \\
(0.0001)\end{array}$ & $\begin{array}{l}1.875 \\
(2)\end{array}$ & $\begin{array}{l}1 \\
2 \\
3 \\
4\end{array}$ & $\begin{array}{c}41.5 \\
39.0 \\
9.8 \\
9.8\end{array}$ \\
\hline $\begin{array}{l}\text { 5. Relationship between CAES } \\
\text { and other government agencies } \\
\text { will not be satisfied }\end{array}$ & $\begin{array}{l}0.71 \\
(0.0001)\end{array}$ & $\begin{array}{l}3.025 \\
(3)\end{array}$ & $\begin{array}{l}1 \\
2 \\
3 \\
4 \\
5\end{array}$ & $\begin{array}{c}9.8 \\
31.7 \\
17.1 \\
29.3 \\
12.2\end{array}$ \\
\hline
\end{tabular}




\begin{tabular}{|c|c|c|c|c|}
\hline \multirow{5}{*}{$\begin{array}{l}\text { 6. CAES increase the regional } \\
\text { imbalance }\end{array}$} & 0.71 & 2.9 & 1 & 14.6 \\
\hline & (0.0001) & & 2 & 24.3 \\
\hline & & (3) & 3 & 22.0 \\
\hline & & & 4 & 19.5 \\
\hline & & & 5 & 14.6 \\
\hline \multirow{5}{*}{$\begin{array}{l}\text { 7. CAES is a hindrance to group } \\
\text { extension service. }\end{array}$} & 0.79 & 2.575 & 1 & 24.4 \\
\hline & $(0.0001)$ & & 2 & 24.4 \\
\hline & & 2.5 & 3 & 31.7 \\
\hline & & & 4 & 7.3 \\
\hline & & & 5 & 12.2 \\
\hline \multirow{5}{*}{$\begin{array}{l}\text { 8. Farmers may have a doubt on } \\
\text { sustaining of the CAES. }\end{array}$} & 0.62 & 2.15 & 1 & 31.7 \\
\hline & $(0.0001)$ & & 2 & 39.0 \\
\hline & & (2) & 3 & 14.6 \\
\hline & & & 4 & 12.2 \\
\hline & & & 5 & 2.4 \\
\hline \multirow{5}{*}{$\begin{array}{l}\text { 9. Farmer is willing to share the } \\
\text { cost of the CAES, not the total. }\end{array}$} & 0.79 & 3.2 & 1 & 22.0 \\
\hline & $(0.0001)$ & & 2 & 17.1 \\
\hline & & (4) & 3 & 9.8 \\
\hline & & & 4 & 22.0 \\
\hline & & & 5 & 29.3 \\
\hline \multirow{5}{*}{$\begin{array}{l}\text { 10. Commercialized Extension } \\
\text { Service will pay attention only to } \\
\text { increase the production without } \\
\text { considering other factors such as } \\
\text { environmental, social etc. }\end{array}$} & 0.62 & 1.875 & 1 & 41.5 \\
\hline & $(0.0001)$ & & 2 & 41.5 \\
\hline & & (2) & 3 & 7.3 \\
\hline & & & 4 & 7.3 \\
\hline & & & 5 & 2.4 \\
\hline \multirow{5}{*}{$\begin{array}{l}\text { 11. Farmer may loose their } \\
\text { independency of decision marking } \\
\text { due to Commercialized Extension } \\
\text { Service. }\end{array}$} & 0.70 & 2.95 & 1 & 17.1 \\
\hline & $(0.0001)$ & & 2 & 22.0 \\
\hline & & (3) & 3 & 24.4 \\
\hline & & & 4 & 22.0 \\
\hline & & & 5 & 14.6 \\
\hline
\end{tabular}

Table 04: Attitudinal Score for Negative Statements

\begin{tabular}{|c|c|c|c|}
\hline $\begin{array}{ll}\text { Category } & \text { for } \\
\text { Negative } & \\
\text { Statements } & \\
\end{array}$ & Attitudinal Score & Frequency & Percentage \\
\hline Least Favorable & $<26.7205$ & 16 & 40.00 \\
\hline Favorable & $26.7205-30.1295$ & 12 & 30.00 \\
\hline Most Favorable & $>30.1295$ & 12 & 30.00 \\
\hline Total & & 40 & 100.00 \\
\hline
\end{tabular}


According to table 04 , about $40 \%$ of farmers have least favorable attitude on CAES based on negative statement. Altogether $60 \%$ farmers have favorable and most favorable attitude towards CAES.

\section{CONCLUSION}

- For the overall attitudinal scale, 19 positive statements and 11 negative statements were selected.

- Farmers have favorable attitudes towards CAES based on both positive and negative statements.

- Considering the positive statements, the following statements revealed the agreement of the farmers to go for commercialization of agricultural extension;

1. Commercialization increases overall efficiency of agric extension service?

2. Commercialization increases overall effectiveness of agric extension service?

3. Extension workers in CAES can maintain good rapport with the research personnel

4. Extension worker in CAES can devote more time for the extension work due to lack of irrelevant duties such as attending to government meetings, political works etc.

5. Farmers believe that government extension service is not doing enough service (inefficient).

6. Extension Workers of the Commercialized Extension Service have good relationships with other support services such as input supplies market, etc.

- The positive statements $3,8,9,10,11,13,15,17, \quad$ and 18 disclosed the moderate agreement and rest of the statements $(2,4$ and 5) disclosed the disagreement about the issue.

- The negative statements that resulted neutral agreement are 5 and 6 . The statements which have been not agreed (positive attitude for negative statement; or double negative law) by farmers are 9 and 11. The agreement for rest of the negative statements $(2,3,4,8$ and 10) revealed the negative attitude for commercialization.

- About $40 \%$ of farmers have least favorable attitude on CAES based on negative statement. Altogether $60 \%$ farmers have favorable and most favorable attitude towards CAES

\section{References}

Chandra Shekara P., (2001). Private Extension in India, Myths, Realities, Apprehensions and Approaches, National Institute of Agricultural Extension Management, India

Chapman, R. R. .Tripp, (2003). Changing incentives for agricultural extension- A review of privatized extension in practice, AgREN Network paper 132, UK

Mahaliyanaarchchi R. P., (2002). Agricultural Extension Service in Sri Lanka, BeraterInnen News, 2/2002, pp10-15

Malkanthi S. H. P., R. P. Mahaliyanaarchchi, (2001), Attitudes of the farmers and agricultural officers on privatization of agricultural extension services in up country vegetable sector in Sri Lanka, Tropical Agricultural Research, Vol 13, pp 319-327 